\title{
Mechanical haemolytic anaemia after valve repair operations for non-rheumatic mitral regurgitation
}

\author{
CAROLE WARNES $\star$, MICHAEL HONEY, NICHOLAS BROOKS, JOHN DAVIES $†$, \\ ANGELA GORMAN \\ From the Department of Cardiology, London Chest Hospital, and the Department of Clinical \\ Haematology, University College Hospital, London
}

SUMMARY Two cases are described in which severe mechanical haemolytic anaemia developed shortly after operation for repair of non-rheumatic mitral regurgitation. One patient had a "floppy" valve and the other cleft mitral leaflets, and both had chordal rupture. In both there was residual regurgitation after repair though in one this was initially only trivial. Clinically manifest haemolysis ceased after replacement of the valve by a frame-mounted xenograft. There are two previously reported cases in which haemolytic anaemia followed an unsuccessful mitral valve repair operation.

Subclinical haemolysis or mild haemolytic anaemia may occur with unoperated valve lesions, but hitherto frank haemolytic anaemia has been observed only when turbulent blood flow is associated with the presence of a prosthetic valve or patch of prosthetic fabric. In these four cases, however, polyester or Teflon sutures were the only foreign material, and it is suggested that when these are used for the repair of leaflets, particularly in non-rheumatic mitral valve disease, they may increase the damaging effect of turbulence on circulating red blood cells.

Mechanical haemolytic anaemia is well recognised as a sequel to open heart operations when there is turbulent blood flow in the presence of prosthetic material. This was first described in a patient who had had an ostium primum atrial septal defect repaired with a Teflon patch, ${ }^{1}$ and later in patients with an aortic Starr-Edwards valve and a paraprosthetic leak. ${ }^{2}$ It is now known that haemolytic anaemia not uncommonly develops in patients who have had their aortic or, less often, their mitral valve replaced by a mechanical prosthesis without such a fault. Subclinical haemolysis can be detected in many of these patients who are not anaemic. Indeed, it can occur in some patients with aortic valve disease before operation. Two patients have been reported in whom haemolytic anaemia followed mitral valve repair. ${ }^{34}$ We have recently seen two similar patients, in both of whom the anaemia was corrected by a second operation to replace the repaired valve.

\footnotetext{
$\star$ Present address: National Heart Hospital, London.

† Present address: Hammersmith Hospital, London.

$¥$ Present address: The Hospital for Sick Children, Great Ormond Street, London.

Received for publication 13 February 1980
}

\section{Case reports}

CASE 1

A 53-year-old microbiology technician had rheumatic fever at the age of 9 . He had been known to have a systolic murmur for at least 25 years. When first seen at the London Chest Hospital in 1966, he had no symptoms of heart disease; he was in sinus rhythm and had a loud mid-late systolic murmur (grade $4 / 6$ ) with a thrill. The heart was not enlarged on the chest $x$-ray film and pulmonary vascularity was normal. The electrocardiogram showed only sharp $T$ inversion in leads III and aVF. He remained asymptomatic till 1974, though the murmur became pansystolic. During this time the blood pressure averaged $170 / 100 \mathrm{mmHg}$. In 1974, he developed atrial fibrillation. Sinus rhythm was restored by direct current countershock but atrial fibrillation recurred two weeks later, despite a small maintenance dose of quinidine (Kinidin durules ${ }^{\star} 1 \mathrm{bd}$ ), and digoxin and practolol were given. After this, his exercise tolerance decreased and there was radiological evidence of increasing heart size and pulmonary venous hypertension.

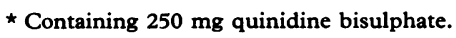


Cardiac catheterisation and left ventriculography in January 1975 showed pure severe mitral regurgition, with cusp prolapse. The pulmonary artery wedge mean pressure was $24 \mathrm{mmHg}$, with a $50 \mathrm{~mm}$ $v$ wave and no mitral end-diastolic gradient.

At operation (Mr J E C Wright), on 19 February 1975, the appearances were those of non-rheumatic mitral regurgitation with ruptured chordae to both anterior and posterior leaflets, which were floppy, redundant, and prolapsing. The posterior cusp was plicated; the prolapsed segment of the anterior cusp was excised as a wedge and the cusp repaired. No prosthetic material was used except for Mersilene (braided polyester) sutures. The postoperative course was uneventful. The haemoglobin level, $15.3 \mathrm{~g} / \mathrm{dl}$ before operation, fell to $9.0 \mathrm{~g} / \mathrm{dl}$ three days after operation, and rose to $14.8 \mathrm{~g} / \mathrm{dl}$ after transfusion. On discharge (6 March) it was $14.6 \mathrm{~g} / \mathrm{dl}$. The blood urea before operation was $59 \mathrm{mg} / \mathrm{dl}$ $(9.8 \mathrm{mmol} / \mathrm{l})$ and on discharge $71 \mathrm{mg} / \mathrm{dl}(11.8$ $\mathrm{mmol} / \mathrm{l})$. He remained in atrial fibrillation, but there were no signs of heart failure. There was now a short late systolic murmur only.

On 28 April 1975, he was again defibrillated electrically, and after this took Kinidin durules $(2 \mathrm{bd})$ until 10 June. On that date he reported diarrhoea, attributed to quinidine, and increasing breathlessness. He was pale and jaundiced, but his cardiac condition was unchanged.

Investigations showed: haemoglobin $7 \cdot 7 \mathrm{~g} / \mathrm{dl}$, red blood cells $3.1 \times 10^{12} / 1$, white blood cells $5.3 \times 10^{9} / 1$ (normal differential), platelets $181 \times 10^{9} / 1$, reticulocytes 7 to 13 per cent, PCV 24 per cent, $\mathrm{MCH}$ $32 \mathrm{pg}, \mathrm{MCHC} 32.0 \mathrm{~g} / \mathrm{dl}$; ESR $140 \mathrm{~mm}$ in 1 hour. The blood film showed many fragmented red blood cells. Blood urea was $55 \mathrm{mg} / \mathrm{dl}(9 \cdot 2 \mathrm{mmol} / \mathrm{l})$, serum bilirubin (all unconjugated) 1.4 to $1.8 \mathrm{mg} / \mathrm{dl}$ (24 to $32 \mu \mathrm{mol} / \mathrm{l}$ ), serum hydroxybutyric dehydrogenase $2324 \mathrm{IU} / 1$, serum lactic dehydrogenase $1020 \mathrm{IU} / 1$, serum haptoglobins $0 \cdot 1 \mathrm{~g} / 1$ (normal 1.0 to $3.0 \mathrm{~g} / \mathrm{l})$, plasma haemoglobin $1.5 \mathrm{~g} / 1$. The urine contained urobilinogen and haemosiderin, but no bilirubin or red blood cells. Schumm's test for methaemalbumin was positive. Serum iron and iron-binding capacity, serum vitamin $\mathrm{B}_{12}$, red cell folate, plasma fibrinogen, haemoglobin electrophoresis, and glucose-6-phosphate dehydrogenase were normal. Other investigations giving negative or normal results were osmotic fragility, Ham's acid-serum test, sucrose-haemolysis test, Heinz body preparation, and antinuclear factor. Direct and indirect antiglobulin (Coombs) tests were repeatedly negative.

Bone marrow aspirate showed active normoblastic erythropoiesis with myeloid/erythroid ratio $1: 1$ and reduced stainable iron. Red cell half-life $\left({ }^{51} \mathrm{Cr}\right)$ was
12.0 days (normal 25 to 28 days); there was no significant splenic sequestration and negligible stool loss. Ferrokinetic studies $\left({ }^{59} \mathrm{Fe}\right)$ showed rapid clearance and 67 per cent utilisation at six days.

He was treated by blood transfusion, oral iron, and folic acid. During the following 18 months, signs of active haemolysis persisted. The haemoglobin level ranged between 8.8 and $11.0 \mathrm{~g} / \mathrm{dl}$ and he required transfusion again in October 1976. He remained in sinus rhythm. There were no signs of heart failure, and he still had only a late systolic murmur at the apex. In August 1976, cardiac catheterisation showed normal right heart and left ventricular end-diastolic pressures, and left ventriculography confirmed mild mitral regurgitation, though a minor degree of cusp prolapse was still visible.

During the next year, the clinical signs of mitral regurgitation increased, with a longer and louder apical systolic murmur, and he became increasingly breathless. Concurrently, there was evidence of increasing haemolysis, with a rapid fall in haemoglobin level, and he required repeated transfusions at progressively shorter intervals-an average of 4 to 6 units a month, and during December 1977, 9 units.

At operation on 1 February 1978, the surgeon (Mr J E C Wright) again noted the floppy mitral valve with redundant cusp tissue and dilated valve ring; both leaflets were once more prolapsing allowing moderate central regurgitation. The valve was excised and replaced by a $33 \mathrm{~mm}$ framemounted xenograft valve (Carpentier-Edwards). After operation, the haemoglobin remained above $12.9 \mathrm{~g} / \mathrm{dl}$ and no further transfusion was necessary. In the two subsequent years, he has remained well with a haemoglobin level of 13.3 to $14.8 \mathrm{~g} / \mathrm{dl}$, and a reticulocyte count repeatedly less than 1 per cent. The blood film is normal, with no fragmented red cells. The red cell half-life $\left({ }^{51} \mathrm{Cr}\right)$ is now 23 days. Serum haptoglobins are normal (more than $1.0 \mathrm{~g} / \mathrm{l})$, and tests for urinary haemosiderin negative. The xenograft valve remains competent, with no audible murmur, though atrial fibrillation recurred and digoxin has been continued.

\section{CASE 2}

A 67-year-old woman was first seen in July 1977 when she gave a one-week history of breathlessness. She was found to be in fast atrial flutter and had signs of severe mitral regurgitation. The chest $x$-ray film showed a slightly enlarged heart and pulmonary venous congestion. She improved with treatment, and sinus rhythm returned. She was anticoagulated with warfarin after an episode of pulmonary 
infarction and also received frusemide, amiloride, and propranolol.

Cardiac catheterisation and left ventriculography showed pure severe mitral regurgitation with a pulmonary artery pressure of $45 / 20 \mathrm{mmHg}$, a $50 \mathrm{~mm} v$ wave in the pulmonary artery wedge pressure record, and no mitral diastolic gradient. Coronary arteriograms were normal.

At operation (Mr J E C Wright) on 23 January 1978 , she was found to have a congenitally abnormal mitral valve with a cleft posterior leaflet and a minor cleft also of the anterior leaflet. There were ruptured chordae to the posteromedial portion of the posterior leaflet which was prolapsing. This was plicated, obliterating the cleft and prolapsing segment. The postoperative course was uneventful. The haemoglobin level was $14.6 \mathrm{~g} / \mathrm{dl}$ before and did not fall below $12.9 \mathrm{~g} / \mathrm{dl}$ after operation. An apical systolic murmur was still audible.

In March 1978, she again had signs of severe mitral regurgitation and was in right-sided heart failure. She was found to be severely anaemic.

Investigations showed: haemoglobin $8.8 \mathrm{~g} / \mathrm{dl}$, red blood cells $3.2 \times 10^{12} / 1$, white blood cells $6.4 \times 10^{9} / 1$ (normal differential), platelets $310 \times 10^{9} / 1$, reticulocytes 2.5 to 4.4 per cent, PCV 29 per cent, $\mathrm{MCH}$ $28 \mathrm{pg}, \mathrm{MCHC} 31 \mathrm{~g} / \mathrm{dl}$; ESR $10 \mathrm{~mm}$ in one hour. The blood film showed fragmented red blood cells. Serum bilirubin was $20 \mu \mathrm{mol} / \mathrm{l}$, serum hydroxybutyric dehydrogenase $536 \mathrm{IU} / 1$, serum haptoglobins less than $0.5 \mathrm{~g} / \mathrm{l}$, and serum iron $6.4 \mu \mathrm{mol} / \mathrm{l}$. Blood urea, serum vitamin $B_{12}$, and serum folate were normal. Schumm's test for methaemalbumin was positive. Antinuclear factor was not present and the direct Coombs test was negative. The urine contained urobilinogen and haemosiderin. Red cell half-life $\left({ }^{51} \mathrm{Cr}\right)$ was 14.0 days, with no increased uptake in the liver or spleen.

Cardiac catheterisation with left ventriculography was repeated and confirmed that there was still severe mitral regurgitation, with a pulmonary artery pressure $70 / 30 \mathrm{mmHg}$ and a $30 \mathrm{~mm} v$ wave in the pulmonary artery wedge pressure record.

At reoperation (Mr J E C Wright) on 24 May 1978 , recurrence of mitral regurgitation was found to be the result of further chordal rupture. The valve was excised and replaced by a $31 \mathrm{~mm}$ framemounted xenograft (Carpentier-Edwards). After operation, the haemoglobin level did not fall below $12 \cdot 0 \mathrm{~g} / \mathrm{dl}$.

In the 20 months since reoperation she has remained in sinus rhythm with competent xenograft valve, though there is a short soft ejection systolic murmur. The haemoglobin level has ranged from 11.8 to $13.9 \mathrm{~g} / \mathrm{dl}$; the blood film is normal with no fragmented red cells and reticulocytes never more than 1.8 per cent. Red cell half-life $\left({ }^{51} \mathrm{Cr}\right)$ is normal (28 days). There is no methaemalbuminaemia. The urine test for haemosiderin, however, is still weakly positive and serum haptoglobins are less than $0.5 \mathrm{~g} / \mathrm{l}$.

\section{Discussion}

Both our patients had non-rheumatic mitral valve disease, the first having a "floppy valve" and the second a cleft mitral leaflet, and in both severe mitral regurgitation developed as a result of chordal rupture. In neither was there any associated cardiac lesion. Though evidence of subclinical haemolysis was not sought, neither patient was anaemic before the operation to repair the mitral valve. In neither case was any prosthetic material (except Mersilene sutures) used in the repair procedure, which involved only plication and/or excision of prolapsing segments of the mitral leaflets.

Severe haemolytic anaemia became manifest within two months of operation in case 2 who already had signs of severe recurrent mitral regurgitation resulting from further chordal rupture. In case 1 , haemolytic anaemia was recognised four months after the mitral repair procedure at a time when he had clinical signs of only minimal mitral regurgitation, and a year later left ventriculography showed that reflux was still only slight. His condition remained stable until two years after operation, but then clinical signs of increasing mitral regurgitation were accompanied by increasing severity of the haemolytic process.

The haemolytic nature of the anaemia in our cases was established by the high reticulocyte count, increased hydroxybutyric dehydrogenase and lactic dehydrogenase, the presence of urobilinogen and haemosiderin in the urine, and the shortened red cell survival time. Methaemalbuminaemia indicated that haemolysis was intravascular and its mechanical origin was suggested by the presence of fragmented red cells. No other cause of haemolysis was found. In case 1 it was suspected initially that quinidine might be responsible, though he had previously taken quinidine without ill effect. Quinidine may cause haemolysis by forming an immune-complex with drug-specific antibody or in the presence of glucose-6-phosphate dehydrogenase-deficient red cells, but no evidence for either of these mechanisms was found. No other drug taken by either patient could be incriminated.

The final proof that the haemolysis was the result of trauma to red cells and related to the valve lesion was supplied by the response to reoperation with replacement of the regurgitant mitral valve. 
In neither case is clinically manifest haemolysis now evident, the haemoglobin level remaining within normal limits with no increase in reticulocyte count. The red cell half-life is normal in case 2 and very slightly reduced in case 1 ; reduced serum haptoglobin levels and weakly positive tests for urinary haemosiderin are, however, evidence of continuing subclinical haemolysis in case 2 .

Anaemia developing after cardiac surgical operations as a result of mechanical haemolysis was first reported by Sayed et al. ${ }^{1}$ in a patient who had had an ostium primum atrial septal defect closed with a patch of Teflon felt, without repair of the cleft anterior mitral leaflet; overt haemolysis ceased after reoperation when exposed Teflon was covered with endothelium. A further five cases of haemolytic anaemia after repair of ostium primum defects were described by Sigler et $a .^{5}$ and Verdon et al. ${ }^{6}$ In all of these the defect had been repaired with a Teflon patch and the cleft mitral leaflet sutured. At reoperation in three of these cases the anterior leaflet of the mitral valve was found to be detached from the Teflon patch used for repair, and in another the patch itself was partially detached; in two the patch was only partially endothelialised. Only two patients survived their second operation ${ }^{56}$ : one was unimproved and at later necropsy there was still an incompetent mitral valve and exposed Teflon; the other was cured by a successful repair operation.

Haemolytic anaemia was first reported in patients after aortic valve replacement by mechanical prostheses in association with paraprosthetic regurgitation, ${ }^{2} 78$ but it soon became apparent that this occurred commonly with competent as well as leaking prostheses ${ }^{9-14}$ and also, but less often, after mitral valve replacement. ${ }^{13}{ }^{15}$ Stohlman et al. ${ }^{16}$ had previously found that intravascular haemolysis occurred in dogs after the insertion of a lucite ball valve prosthesis (Hufnagel type) between the left ventricular apex and descending thoracic aorta.

The features common to all these cases are turbulent blood flow resulting from the presence of a mechanical prosthesis and/or paraprosthetic leak or from mitral reflux in ostium primum defects, and the presence of prosthetic material in the circulation. Nevaril et al. ${ }^{17}$ showed that the morphological changes induced in red cells exposed to shearing stress in vitro were similar to those seen in patients with prosthetic valves and haemolytic anaemia and suggested that a shearing mechanism might be responsible in these cases.

Subclinical haemolysis with shortened red cell survival time, and/or reduced serum haptoglobin levels, and increased serum lactic dehydrogenase or hydroxybutyric dehydrogenase, occurs in many patients with prosthetic valves of all types. ${ }^{11} 18-22$ Such patients may not be anaemic, but, because intravascular haemolysis is accompanied by loss of iron as haemosiderin in the urine, a secondary iron-deficiency anaemia may develop ${ }^{11}$ even if bone marrow activity is sufficient to compensate for red cell loss.

There have been a few reports of cases of mechanical haemolytic anaemia in association with unoperated valvar disease, usually aortic,,$^{11}{ }^{23-25}$ and when large numbers of patients with aortic valve disease have been carefully investigated, evidence of subclinical haemolysis has been found in a small proportion. ${ }^{10} 11192526$ In some patients, reduced haptoglobin levels and fragmented red cells may be the only evidence of haemolysis, and red cell survival times may be normal. ${ }^{27}$

We have found only two previous reports of the development of clinically important haemolytic anaemia in patients with mitral regurgitation, and in both cases this followed a repair operation. Ziperovich and $\mathrm{Paley}^{3}$ described a patient with rheumatic heart disease who developed mitral regurgitation after a closed mitral valvotomy; massive mitral regurgitation recurred after mitral valve repair (using Tevdek sutures) and severe haemolytic anaemia then developed, with reticulocytosis $(13 \%)$, jaundice, methaemalbuminaemia, haemoglobinuria, and absent haptoglobins. Clinical haemolysis ceased after replacement of the valve by a Starr-Edwards prosthesis, but serum haptoglobins were still low. Moisey et al. ${ }^{4}$ observed the development of severe haemolytic anaemia within three weeks of an unsuccessful operation for repair of a cleft mitral anterior leaflet (with polyester sutures) in a 4-year-old child who had previously had a coarctation resected. At reoperation a "loose suture" was observed; after replacement of the valve by a Starr-Edwards prosthesis, haemolytic anaemia did not return, though the red cell halflife was still reduced.

Three of the four cases described (these two and one of our own) still had severe mitral regurgitation after the repair procedure at the time when the haemolytic anaemia became manifest, though our first patient had only trivial mitral regurgitation when he first became anaemic, much less than before operation. Since haemolytic anaemia rarely, if ever, occurs in patients with unoperated mitral regurgitation it is difficult to escape the conclusion that even polyester or Teflon suture material, if critically placed in the path of turbulent blood flow, can increase the damaging effect of turbulence on circulating red cells sufficiently to cause clinically apparent haemolysis. It is possible that the nonrheumatic mitral valve cusp after repair retains 
sufficient mobility and flexibility to inhibit the growth of "endothelium" over the suture material, though in our cases no observations were made to substantiate this at the time of reoperation. In all four cases replacement of the repaired valve by a prosthesis or zenograft abolished the anaemia, though evidence of subclinical haemolysis was still present in three.

We are grateful to Mr J E C Wright who performed the mitral repair and replacement operations in both cases, and to Professor T A J Prankerd and Dr E C Gordon-Smith for help with the investigation and management of these patients.

\section{References}

1 Sayed HM, Dacie JV, Handley DA, Lewis SM, Cleland WP. Haemolytic anaemia of mechanical origin after open heart surgery. Thorax 1961; 16: 356-60.

2 Marsh GW. Intravascular haemolytic anaemia after aortic valve replacement. Lancet 1964; ii: 986-8.

3 Ziperovich S, Paley HW. Severe mechanical hemolytic anemia due to valvular heart disease without prosthesis. Ann Intern Med 1966; 65: 342-6.

4 Moisey CU, Manohitharajah SM, Tovey LAD, Deverall PB. Hemolytic anemia in a child in association with congenital mitral valve disease. f Thorac Cardiovasc Surg 1972; 63: 765-8.

5 Sigler AT, Forman EN, Zinkham WH, Neill CA. Severe intravascular hemolysis following surgical repair of endocardial cushion defects. Am $\mathcal{F}$ Med 1963; 35: 467-80.

6 Verdon TA Jr, Forrester RH, Crosby WH. Hemolytic anemia after open heart repair of ostium primum defects. $N$ Engl f Med 1963; 269: 444-6.

7 Reed WA, Dunn M. Fatal hemolysis following ball valve replacement of the aortic valve. $\mathcal{f}$ Thorac Cardiovasc Surg 1964; 48: 436-42.

8 Stevenson TD, Baker HJ. Haemolytic anaemia following insertion of Starr-Edwards valve prosthesis. Lancet 1964; ii: 982-5.

9 Brodeur MTH, Sutherland DW, Koler RD, Starr A, Kimsey JA, Griswold HE. Red blood cell survival in patients with aortic valvular disease and ball-valve prostheses. Circulation 1965; 32: 570-81.

10 Dupont B, Wennevold A. Mechanical hemolytic anemia in unoperated aortic valve disease. Acta Med Scand 1968; 184: 353-7.

11 Eyster E, Mayer K, McKenzie S. Traumatic hemolysis with iron deficiency anemia in patients with aortic valve lesions. Ann Intern Med 1968; 68: 995-1004.

12 Yacoub MH, Keeling DH. Chronic haemolysis following insertion of ball valve prostheses. Br Heart f 1968; 30: 676-8.

13 Rodgers BM, Sabiston DC Jr. Hemolytic anemia following prosthetic valve replacement. Circulation 1969; 39, suppl I: 155-61.

14 Dave KS, Madan CK, Pakrashi BC, Roberts BE, Ionescu MI. Chronic hemolysis following fascia lata and Starr-Edwards aortic valve replacement. Circulation 1972; 46: 240-9.

15 Marsh GW. Mechanical haemolytic anaemia after mitral valve replacement. $B r$ Med F 1966; ii: 31-32.

16 Stohlman F Jr, Sarnoff SJ, Case RB, Ness AT. Hemolytic syndrome following the insertion of a lucite ball valve prosthesis into the cardiovascular system. Circulation 1956; 13: 586-91.

17 Nevaril CG, Lynch EC, Alfrey CP Jr, Hellums JD. Erythrocyte damage and destruction induced by shearing stress. f Lab Clin Med 1968; 71: 784-90.

18 Veneziale CM, McGuckin WF, Hermans PE, Mankin HT. Hypohaptoglobinemia and valvular heart disease: association with hemolysis after insertion of valvular prostheses and in cases in which operation had not been performed. Mayo Clin Proc 1966; $41: 657-62$.

19 Walsh JR, Starr A, Ritzmann LW. Intravascular hemolysis in patients with prosthetic valves and valvular heart disease. Circulation 1969; 39, suppl I: 135-40.

20 Crexells C, Aerichide N, Bonny Y, Lepage G, Campeau L. Factors influencing hemolysis in valve prosthesis. Am Heart $\mathcal{F}$ 1972; 84: 161-70.

21 Nitter-Hauge S, Sommerfelt SC, Hall K-V, Fröysaker T, Efskind L. Chronic intravascular haemolysis after aortic disc valve replacement. Comparative study between Lillehei-Kaster and Björk-Shiley disc valve prostheses. Br Heart $\mathcal{F}$ 1974; 36: 781-5.

22 Nitter-Hauge $S$. Haemolysis after mitral valve replacement with the Björk-Shiley and the LilleheiKaster disc valve prosthesis. $\mathrm{Br}$ Heart $\mathcal{f}$ 1976; 38: 977-80.

23 Massachusetts General Hospital. Case 52: 1964. $N$ Engl f Med 1964; 271 : 898-905.

24 Miller DS, Mengel CE, Kremer WB, Gutterman J, Senningen $\mathbf{R}$. Intravascular hemolysis in a patient with valvular heart disease. Ann Intern Med 1966; 65: $210-5$.

25 Westring DW. Aortic valve disease and hemolytic anemia. Ann Intern Med 1966; 65: 203-9.

26 Grosse-Brockhoff F, Gehrmann G. Mechanical hemolysis in patients with valvular heart disease and valve prosthesis. Am Heart $\mathcal{f}$ 1967; 74: 137-9.

27 Yacoub MH, Rogers K, Crossland-Taylor P. Red cell survival in patients with aortic valve disease. Thorax 1965; 20: 367-9.

Requests for reprints to $\mathrm{Dr}$ Michael Honey, London Chest Hospital, Bonner Road, London E2. 